\section{Halley's comet in ancient times}

SIR - In his comment on the Babylonian observations of Halley's comet ${ }^{1}$, C.B.F. Walker states that in Mesopotamia "almost all the early texts are concerned with astrology rather than astronomy". Walker continues by noting that the earliest astronomical observations known to Ptolemy in circa AD 150 dated "from the time of the Babylonian king Nabonassar (747-734 BC)'". Both these points deserve comment.

First, although doubts have been expressed as to the link between astrology and astronomy in Babylonian times (for example, ref. 3), there is no firm evidence that the powerful temple priests of Mesopotamia made any distinction between what we call by the separate names of "astrology" and "astronomy": facility in expounding the former necessitated skill in understanding the latter.

Second, Sawyer and Stephenson showed in 1970 (a hypothesis confirmed by Muller and Stephenson in 1975) $)^{4}$ that what was in all likelihood a total solar eclipse was observed during daytime at Ugarit on 3 May 1375 BC. It seems fair to assume (although the details were not known to Ptolemy in AD 150 and are still not known fully to us now) that astronomical observations took place in and around Mesopotamia for a considerable period of time before $747 \mathrm{BC}$.

MARTIN PULBROOK

\section{Department of Ancient Classics,}

St Patrick's College,

Maynooth, Co. Kildare, Ireland

1. Stephenson, F.R., Yau, K.K.C. \& Hunger, H. Nature 314, 587 (1985).

2. Nature 314, $576(1985$

3. Clagett, M. Greek Science in Antiquity, 11 (Books for Libraries Press, Plainview, New York, 1971.

4. Stephenson, F.R. and Clark, D.H. Applications of Early Astronomical Records (Adam Hilger, Bristol, 1978), 43-44.

\section{Embryo research}

SIR - Professor J.A. Davis (Nature 25 April, p.666) wonders whether a "legally or morally valid distinction" can be made between negatively interfering to stop a natural process, for example by procuring the abortion of a fetus in utero, and simply refraining from "positive intervention required for its survival", by not putting an egg fertilized in vitro into a woman, without which it must inevitably die.

But there is at any rate a legal difference between intentionally killing someone and doing nothing to save him. You are under no legal obligation to rescue a drowning man, and if you feel morally obliged to jump in to help him that is a matter for your own conscience, and no concern of the law. But to push him in deliberately is certainly a criminal offence, and probably murder if he drowns.

Professor Davis rightly understands that the argument in my last letter (Nature 14
March, p.126) could not be used to justify aborting an embryo that had already started on its normal development in utero, but that it might allow experimentation with embryos generated in vitro which, undoubtedly human as they are, cannot of themselves realize their potential for further development without some positive act of intervention from outside.

The Warnock Committee (Report, para. 11.22) proposed a limit of 14 days for keeping an embryo alive in vitro (otherwise than frozen), whether or not is was used for experimental work, and nobody seems to have suggested that this should be much extended. But it should be noted that experiments with living fetuses that have been legally aborted before the age of viability, that is to say up to something over 20 weeks gestation age, are not prohibited under English law. These are by definition doomed to die but they can be kept alive for at least several hours, and considerable publicity was given some years ago to attempts at Cambridge to develop an artificial placenta, using a human fetus which from press photographs appeared to be of 16-18 weeks gestation age. Although the Warnock Report (p.64) has suggested that the law ought to be reconsidered in this respect, such work is at present still quite legal, even if it is not for the squeamish.

C.B. GOODHART

University Department of Zoology,

Downing Street,

Cambridge CB2 3EJ, UK

\section{Artificial hearts}

SIR - Your leading article "Hearts in the wrong place"' (Nature 21 March, p.206) classifies you among the modern legal luddites, glorifying form over substance and accepting the idea that the lawyerregulators know best, regardless of the consequences of their actions.

You admit that Dr Copeland's patient would clearly have died without the use of the artificial heart. In the light of this, neither the patient nor the patient's family was harmed by the heart's insertion and important information was obtained which may well allow the effective use of such hearts or improved models in the future.

There was also the possibility, albeit remote, that the artificial heart might have preserved the patient's life for a long enough time to allow for a successful implantation of a new human heart.

Thus the only potential results of the use of the heart were beneficial, even your editorial writer being unable to discover anyone who had been harmed. The use of available technology in such situations should be encouraged and not barred. In view of the admitted benefits and lack of harm to anyone, Dr Copeland deserves commendation not condemnation.

School of Law,

Seton Hall University,

1111 Raymond Boulevard,

Newark, New Jersey 07102, USA () 1985 Nature Publishing Group

\section{Value-free science}

SIR - Mark Diesendorf (Nature 10 January, p.92) questions the notion of value-free science, which I discuss in my letter of 27 September 1984 (p.294). Unfortunately, his comments suffer from the very confusion of categories that I tried to clarify. Since this error has marred much of the discussion of the subject, and since my explanation was excessively brief, it seems worthwhile to consider further what we mean by "science" and by "value-free" or "objective".

The word "science" is ordinarily used to refer to three things: a methodology, a resulting body of knowledge and the ensemble of activities of those who professionally use that methodology. The methodology has evolved a set of canons, and a social framework, designed to ensure maximal objectivity and reliability of the resulting knowledge. On the other hand, the activities of scientists are indeed filled with subjective value judgments: by the individual (what problem to work on, how to approach it, how to present the results), and also by social organizations (what to support, what to accept for publication, how to translate scientific knowledge into technological practice). But despite this subjective element, if the science is honest the practitioner must try to make its content - the data and the logical inferences drawn from them - as objective as is humanly possible. He may not succeed perfectly, but at least he should not deliberately inject ideological or other biases.

Diesendorf further calls attention to such presumbably value-laden terms as "fashionable" and "confusion" in my letter. I would suggest that these terms are actually capable of being objectively assessed. But more fundamentally, valueladen terms would not be out of place. For discussions of the nature of science constitute still another category, to be distinguished from the three noted above: they are metascience, presenting philosophical judgments rather than objective knowledge.

Finally, I agree with Diesendorf that problems involving social value judgments should not be treated as though they were purely technological, and his example of planning how to generate electricity fits. But I believe he errs in similarly categorizing the risk of fallout from nuclear weapons. It is a technical question, whose answer then becomes part of the broader question of what to do about these weapons. With the growth of technological innovation we face an increasing number of such questions (for example, the dangers of biotechnology), and we impair our analysis if we do not try to separate their technical from their social aspects.

BERNARD D. DAVIS

Bacterial Physiology Unit,

Harvard Medical School,

Boston, Massachusetts 02115, USA 